Itinéraires Itinéraires

Littérature, textes, cultures

2019-2 et $3 \mid 2019$

Corps masculins et nation : textes, images, représentations

\title{
Performances of Gender in Revolutionary Contexts: The Case of Nicaragua
}

Performances de genre en contextes révolutionnaires: le cas du Nicaragua

\section{Viria Delgadillo}

\section{(2) OpenEdition}

\section{Journals}

Electronic version

URL: http://journals.openedition.org/itineraires/6929

DOI: $10.4000 /$ itineraires.6929

ISSN: 2427-920X

Publisher

Pléiade

\section{Electronic reference}

Viria Delgadillo, "Performances of Gender in Revolutionary Contexts: The Case of Nicaragua »,

Itinéraires [Online], 2019-2 et 3 | 2019, Online since 13 December 2019, connection on 15 December

2019. URL : http://journals.openedition.org/itineraires/6929; DOI : 10.4000/itineraires.6929

This text was automatically generated on 15 December 2019 .

\section{cc) $(\mathrm{B} \odot$}

Itinéraires est mis à disposition selon les termes de la licence Creative Commons Attribution - Pas d'Utilisation Commerciale - Pas de Modification 4.0 International. 


\title{
Performances of Gender in
}

\section{Revolutionary Contexts: The Case of Nicaragua}

\author{
Performances de genre en contextes révolutionnaires : le cas du Nicaragua
}

\author{
Viria Delgadillo
}

\section{Introduction}

1 Gender policies were at the heart of the 1980s Frente Sandinista de Liberación Nacional's (FSLN) plans for social change. These policies were crucial to the legitimation of the Sandinista government, both domestically and abroad. In the existing literature on the Nicaraguan revolution, the issues of gender and legal reform as well as gender and revolutionary ideology have been dealt with at length. Molyneux's (2001), Kampwirth's (1998, 2006, 2013, 2015) and Montoya's (2003) illuminating works on Sandinista law-making and gender ideology address how revolutionary ideology shapes legislation regarding women, LGBTQI individuals and the family. However, these analyses do not explore in detail the different ideological forces that shaped revolutionary masculinity and prevented effective social and legislative change. This paper will thus address the following question: How did revolutionary ideology impact public and private gender performances in Nicaragua?

In order to address this question, and given cultural, ideological and historical similarities, early revolutionary Cuba will serve as an example of the ideological difficulties of constructing gender and revolutionary subjectivity after a successful revolution in the Latin American context. Firstly, I will examine the instrumentalization of the idea of the socialist "new man" in Cuba's and Nicaragua's revolutionary movements, as well as their apparent need to redefine masculinity, by drawing on the analyses of Ileana Rodríguez (1996), Saldaña-Portillo (2003), Kampwirth $(1998,2006,2013,2015)$ and Lumsden (1996). In the subsequent analysis, Bourdieu's 1996 analysis of the family as a realized category and the role of the state in the 
delineation of the public and the private, as well as Althusser's analysis of sociopolitical repression (1970), will be instrumental for addressing the establishment and performance of revolutionary gender ideology.

\section{The Guerrillero and the New Man: Where are the Guerrillera and the Homosexual Patriot?}

3 Patriarchal ideology and its structuring of societal power relations, as Ian Lumsden asserts in Machos, Maricones and Gays (1996), determine how men relate to each other and to women. He argues that, "[in] general, there is a correlation between the oppression of women and the oppression of homosexuals," which is consistent with the ideological exclusions or omissions found in Latin American revolutionary rhetoric and political discourse (1996: 28). The way language is employed in revolutionary discourse is partcularly pertinent to the analysis of gender-based oppresion because it tends to model the way ideology is performed and social reality constructed. As explained by Bourdieu, "in the social world, words make things, because they make the consensus on the existence and the meaning of things, the common sense, the doxa accepted by all as self-evident" (1996: 21). Thus, to examine how the performance of revolutionary gender ideology affected both men and women in Nicaragua, it is necessary to deconstruct revolutionary discourse and question the judgments and beliefs that it presents as self-evident.

Ernesto "Che" Guevara's 1965 letter, Socialismo y el hombre en Cuba, is one of the most influential revolutionary documents, which put forth the idea of the guerrillero as the one responsible for the creation of the new socialist society. This letter genders revolutionary subjectivity and seems to negate the existence of the guerrillera:

The leaders of the revolution have children just beginning to talk, who are not learning to say "daddy"; their wives, too, must be part of the general sacrifice of their lives in order to take the revolution to its destiny. The circle of their friends is limited strictly to the circle of comrades in the revolution. There is no life outside of it. ${ }^{1}$ (Guevara [1965] 1977: 270)

Women in revolutionary narratives exist mostly in relation to men. The revolutionary leaders' "mujeres" (women, i.e. wifes/mothers) are only referred to as part of the general sacrifice, made by the male revolutionary leaders, who are the responsible political agents. Revolutionary and political action are thus conceived of as belonging exclusively to the male sphere of possibilities. The traditional heterosexist model of masculine identity imposed on the revolutionary subject is founded on the "male breadwinner/female homemaker" family model and reaffirmed by suggesting that abandoning domestic roles (father/husband) is acceptable, even necessary, for men, who belong in the public, political sphere (Atkinson 2013: 225). Indeed, fatherhood is not usually perceived as a defining feature of manhood, especially in times of war, whereas the opposite tends to be true of motherhood, which often becomes politicized in times of crisis. ${ }^{2}$

5 To access revolutionary subjectivity, men are to renounce their identities as fathers and husbands, as these are deemed inessential to masculinity. The identities of revolutionary subject and father/husband are presented as mutually exclusive and the call to defend the nation has to take precedence over domestic duties, which are not seen as necessary for survival and are thus feminizing. Therefore, dominant notions of 
family within revolutionary discourse largely determined how male and female subjects were asked to perform revolutionary ideology. For family discourse is a "powerful, performative discourse, which has the means of creating the conditions of its own verification and therefore its own reinforcement, an institutional discourse which durably institutes itself in reality" (Bourdieu 1996: 25).

The guerrillero, often interpreted in the Latin American revolutionary context as the New Man, must sacrifice domestic life, which is only suitable for women, children and the elderly, in order to defend the motherland in the name of those who are deemed unable to do so. ${ }^{3}$ In La Montaña es Algo Más que una Inmensa Estepa Verde, ${ }^{4}$ an influential testimony that became representative of the Sandinista guerrilla experience, Omar Cabezas' rhetoric and conception of the New Man mirror those of Guevara. Cabezas' bildungsroman presents a detailed account of his decision to join the FSLN, focusing on how his guerrilla experience shaped his revolutionary consciousness. Rodríguez analyzes the heterosexist construction of the New Man ideal found in Cabezas' testimony and points out that in the narrative "the new man is born with an injunction, that he is not to be a 'little woman,' he is not to be a 'faggot"' (1996: 46). Thus, male homosexuality tends to be equated with feminine subjectivity, which in revolutionary discourse is characterized by the inability to express patriotism through political action.

7 Indeed, the heterosexuality of the nationalist, patriotic revolutionary subject is constantly reiterated in revolutionary discourse. It is through the productive expression of sexuality that revolutionary masculinity is reasserted. The patriot fights for the motherland, which establishes a relationship between "erotic love (the heterosexual love of men for women) and patriotic love (the homosocial love for men and of men for their country)" (Rodríguez 1996: 19). Yet, in spite of the homoerotic undertones of guerrilla narratives, the prevailing machismo and heterosexist notions of the New Man ideology preclude the possibility of a homosexual patriot.

8 The rhetoric found in Guevara's letter also precludes the possibility of women as political agents in the revolutionary struggle. For, it reproduces the masculinist logic that assigns women to the domestic sphere-conceived of as an inherently feminine space-while assigning men to the public sphere, where they may "take the revolution to its destiny" (Rodríguez 1996: 33). This dichotomy that genders public and private spaces can be found extensively in Latin American revolutionary discourse, as evidenced by Rodríguez (1996) and Saldaña-Portillo (2003). Women's exclusion from the new Cuban, revolutionary identity resulted partly from the particular historical context of the revolution (i.e. the 1960s, before the formation of the international women's movements) and the fact that the participation of women in the revolution was not as conspicuous as in Nicaragua or El Salvador (Luciak 2001: chap. 1).

However, in spite of the widely acknowledged participation of women in the Sandinista movement, the logic of masculinist national ideology that confines women to a secondary, supportive, domestic role remained present in the FSLN's revolutionary narrative. Even though some high-profile members of the Sandinista party, such as Carlos Nuñez, head of the National Assembly in the 1980s, were known advocates of women's rights, motherhood was frequently presented in official discourse as women's main contribution to the revolution (Kampwirth 1998). Thus, official discourse often disregarded the key revolutionary role played by guerrilleras, such as Dora María Tellez, who was in charge of the successful Operación Chanchera in $1972,{ }^{5}$ which was crucial in 
advancing revolutionary efforts. Indeed, the constant reiteration of the idea that motherhood is the most important part of women's identities diminishes the political visibility of other expressions of female resistance within the revolutionary context. Moreover, the notion that motherhood, specifically, the production of sons, is the greatest possible female contribution to the revolution devalues all other contributions made by women, and might even partially efface them as activities that can be constitutive of women's identities.

\section{The Feminized Masses and the Enlightened Guerrilleros}

The revolution was frequently presented by male political actors in leadership positions as a resistance movement carried out by men and organized by a morally and politically enlightened male leadership. The agency of women and the oppressed, uneducated "masses" (e.g. male peasants, poor urban dwellers) in taking back the nation from imperialist forces is frequently undermined by the stress placed on the actions of educated, revolutionary male leaders, as illustrated by these passages from Guevara's "Socialismo y el hombre en Cuba":

Then came the stage of guerrilla struggle. It developed in two distinct environments: the people, the still sleeping mass that had to be mobilized; and its vanguard, the guerrillas, the motor force of the mobilization, the generator of revolutionary consciousness and militant enthusiasm. This vanguard was the catalyzing agent that created the subjective conditions necessary for victory. [...] This was the first heroic period, and in which combatants competed for the heaviest responsibilities, for the greatest dangers, with no other satisfaction than fulfilling a duty. [...] In the attitude of our fighters could be glimpsed the man and woman of the future. ${ }^{6}$

In the first passage, the "mass" of people who participated in the revolutionary process is presented in a secondary, passive role, while the guerrilla is presented as the main creator and mobilizing agent of the revolution. The mass of people who support the revolution outside the guerrilla and the wives of revolutionaries, mentioned earlier, are presented in a similar way. That is, they are both seen as implicated in the revolutionary process solely through their connection to the male combatants; the mass, like the wives, depends on the revolutionaries' guidance and moral and intellectual superiority.

11 The second passage illustrates the kind of revolutionary heroism that the guerrilleros are capable of thanks to their revolutionary outlook and education. Guevara's description of heroic, virile, risk-taking manhood resonates with that which Fonseca presents in Ideario Politico del General Sandino (1966) in Nicaragua. The New Man is someone who is capable of exposing himself to danger simply out of a sense of duty. This heroic masculine selflessness, proactiveness and determination is contrasted with the mass that was "still fast asleep [todavía dormida]" and thus, passively waiting to be moved to action. The mass, which also includes men who did not join the guerrilla struggle, is then seen, much like women, as a malleable entity that complements masculine revolutionary efforts in the Cuban politico-military narrative.

This kind of rhetoric is echoed by Sandinista leader, Tomás Borge, who, in a meeting with the Inter-American Human Rights Commission in October, 1980, had to account for the abuses committed by the guerrilleros and Sandinista militants after overthrowing Somoza, including massive looting and extrajudicial executions. He 
argued that he could not in good conscience punish those who had served the revolution and further added:

[D]o we really have the moral right to punish those who fought alongside the people against the tyranny, who risked their lives, who perhaps were wounded, who saw their fathers and brothers and sons killed? (Borge et al. 1982: 89)

But we cannot demand the same consciousness from the great mass of fighters who saw their brothers and sons shot down, whose wives were raped, whose daughters were raped [...]. (Ibid.: 89)

The people did it; the people themselves did the looting; the people themselves did the killing. [...] There was a virtual explosion in Nicaragua, and the only reason it wasn't worse was because of the good sense, maturity, and respect for humanity that motivate the leaders of the revolution. (Ibid.: 103)

In the third citation, there is a clear presentation of the masses as irrational and immature while the leadership is presented as the moderating, rational force that shapes the revolutionary movement. ${ }^{7}$ In this way, Borge simultaneously diffuses responsibility for abuses committed by the revolutionary leadership and underscores their superior moral character. The "new men" that led the revolution are presented in contradistinction to the masses, which are denied the capacity to reason and are infantilized by their lack of "maturity." The male leaders are presented as the ones capable of guiding the people, like children, towards a better society. This paternalist logic based on the moral superiority of the leadership is further illustrated in the first citation, where Borge refuses to punish the offenses of revolutionaries who risked their lives for the revolution and saw their "fathers and brothers and sons killed." Male family members who died in the struggle to topple Somoza's dictatorship are thus given political visibility in an attempt to excuse extrajudicial executions.

The political value of fathers, brothers and sons killed in battle is central to the heroic, patriotic politico-military narrative. On the other hand, the political and moral value of the women who died in battle seems to be nullified. Instead of extending the heroic character of selfless sacrifice to women in battle, there is a tendency to present them as victims of sexual violence, as illustrated by the second citation. Their bodies are then simultaneously sexualized and presented as susceptible to invasion and desecration. The bodies of the guerrilleras killed in battle are no longer feminine bodies, but bodies that have been masculinized by occupying the masculine symbolic space of the battlefield. This failure to discursively incorporate the identity of guerrilleras into women's possible subject positions negates one of the most influential aspects in the emergence of women's liberation efforts in Nicaragua. ${ }^{8}$ Moreover, the identification of women as primarily mothers and wives, as showcased by Guevara's letter, also contributes to the delimitation of the identity of the "new man" and what is expected of him in relation to women, ${ }^{9}$ the family and society.

\section{Looking for the New Woman and the Guerrillera: The Revolution within the Revolution ${ }^{10}$}

After the Cuban revolution's successful overthrow of Batista in 1959 there was great impetus, due to the needs brought about by economic restructuring, to present men and women as equally capable of carrying out productive labor in the public sphere. In spite of this need to incorporate as many people as possible into different productive sectors, spaces (especially political spaces) continued to be gendered, and consequently 
womanhood and manhood were often defined in opposition to each other. A similar phenomenon would appear twenty years later in Sandinista Nicaragua in the 1980s. Indeed, the "new women" depicted in art murals commissioned by the Sandinista government ${ }^{11}$ are presented as being finally free to safely revert to the woman of the past, i.e., the woman who had no need to occupy the public sphere and emulate the masculine by taking up arms while remaining feminine by taking care of the wounded and assisting in "feminine" tasks (Moya Fábregas 2010).

This impulse to contain femininity is visible in Guevara's 1960 Guerra de Guerrillas, which was widely influential in Latin American guerrilla organizations. Guevara's description of women's roles in the revolution naturalizes women's domestic skills, presenting their taking up arms as a rare occurrence only found when there are no more men to carry arms:

In this period, women can perform their habitual tasks of peace and it is very pleasant for a soldier [...] to be able to count on well-seasoned food [...] Women can perform an important role as a nurse, and even as a medical doctor, with tenderness infinitely superior to that of the rough comrade in arms. [...] At every level of civil organization, women can lend a hand and perfectly replace men, and they must do so even in case of a lack of arm-bearing soldiers, although this is a very rare incident in guerrilla life. ${ }^{12}$ (Guevara [1960] 1972: 132-33)

Thus Guevara presents women as capable of contributing to revolutionary efforts mainly by performing the domestic roles of cooks, teachers, sewers and carers in the public sphere. But, he also stresses women's duty to replace men in non-feminine activities, such as armed struggle, when necessary. This means that the place of women is clearly defined as noncombative, even in times of war. The "habitual tasks of women in times of peace" ("tareas habituales de la paz") are put forth as means of comforting and supporting the men who risk their lives for the revolution. Women are presented as inherently tender, in contrast to the "tough" ("rudo") compañero, and their cooking as better than that of men. Men are presented as incompetent in all things domestic and women as versatile, malleable and disciplinable, capable of fulfilling any task that the masculinist revolutionary endeavors require of them. ${ }^{13}$

As a subordinated identity, womanhood is more flexible in terms of the subject positions that it can occupy without challenging masculine dominance in the public sphere. Revolutionary masculinity, on the other hand, could not admit such tractability due to its hegemonic status in the politico-military narrative, where feminization amounts to a loss of privilege. Indeed, women's official incorporation in the public sphere was not accompanied by men's equal participation in the private sphere due to the feminizing character of non-productive or unpaid caring labor. ${ }^{14}$ Yet, the masculine space of the battlefield is not feminized by the participation of women in warfare, for the violence, determination and sacrifice that is concomitant with it is construed as pertaining to men. Guevara's attempt to naturalize the auxiliary role of women in the revolution fails to take into account the insistence of Celia Sánchez and other women to join the armed struggle in Cuba, eventually leading to the creation of the all-women platoon "Mariana Grajales" in 1958 (Chase 2015: 128).

17 In the Sandinista revolution, on the other hand, the participation of women was very prominent, with many, such as Doris Tijerino, Leticia Herrera and Dora María Téllez, occupying high-ranking military positions. Yet, the new woman envisioned by the Sandinista leadership was one that would be free to peacefully fulfill her "habitual" 
domestic roles, as shown by Plaza Azuaje in her analysis of murals in Sandinista Nicaragua. She notes that in the murals of the first half of the revolutionary decade:

The revolution is presented as an exclusively masculine quality, and [...] the image of the female combatant is relegated to a secondary role. [...] The murals are overwhelmingly optimistic, full of promises of a better life, [...] a world full of games with children running freely under the look of their happy mothers. ${ }^{15}$ (Plaza Azuaje 2010: 14)

This idyllic imagining of a future that omits the image of the female combatant was rejected by the Asociación de Mujeres Nicaragüenses Luisa Amanda Espinoza (AMNLAE), the Sandinista-affiliated women's organization, through the murals that it commissioned for its branches in Managua, Jinotepe and Diriamba (Ibid.). In these murals, the image of Orlando Valenzuela's 1982 photograph Miliciana de Waswalito, a combatant breastfeeding her baby with her rifle slung over her shoulder, figured prominently. The emphasis placed on female militancy seemed to simultaneously glorify the revolutionary struggle as the means to achieve women's emancipation and remind the audience that women were central to the sociopolitical process that made emancipation possible.

AMNLAE's commissioned murals depicted the "new women" occupying multiple spaces and carrying out sundry tasks, while also incorporating the image of the militant mother, thereby simultaneously refusing to construct a monolithic image of femininity and emphasizing the importance of women's role during the revolution (Plaza Azuaje 2010: 18). The womanhood constructed in revolutionary struggle, at least according to AMNLAE's representations, is versatile since it encompasses both the "feminine" capability for gentleness and nurturing and "masculine" proactiveness and military prowess, while also being intrinsically and unequivocally attached to the feminine role of motherhood. Indeed, AMNLAE's murals seem to imply that in order to attain political personhood, the acquisition of masculine power through participation in the battlefield and thus the performance of the masculine became necessary (Plaza Azuaje 2010: 1617). This performance was validated by the legitimating agents of the revolution, that is, the male revolutionaries. This acquiescence to female participation in the guerrillas, which took several years to cultivate (Luciak 2001 : chap. 1), can be partly attributed to the need to recruit as many members into the guerrillas as possible, especially in the second half of the 1970s.

AMNLAE's reiteration of the presence of the guerrillera in the struggle underscores women's acquisition of masculine power through militant participation in the revolution and concurrently refuses to relinquish what seems to be interpreted as the quintessentially feminine, i.e. motherhood. AMNLAE's image of revolutionary femininity seems to attempt to reconcile women's active role in the battlefield with the traditional role of mother/homemaker. Coincidentally, this image seems to echo the FSLN's refusal to grant women reproductive rights and access to contraceptives, for the leadership, too, due to the dominant Christian ideology and prevailing machista sentiments in the FSLN hierarchy, ${ }^{16}$ construed motherhood as essential to womanhood and thus as something that could still be imposed on women.

\section{The Iconic Guerrillera and the Quintessential New Man}


Fig.1. Alberto Korda, Guerrillero Heroico ${ }^{17}, 1960$ (photo in the public domain).

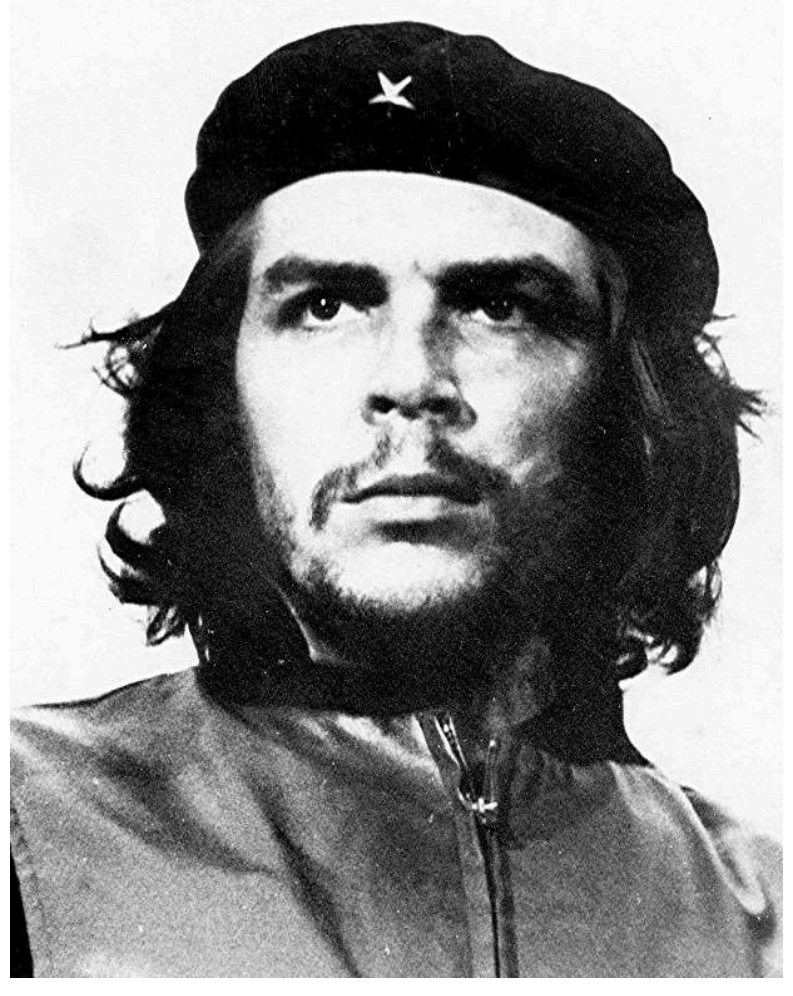

Fig. 2. Orlando Valenzuela, Miliciana de Waswalito, 1982 (reproduced with author's permission).

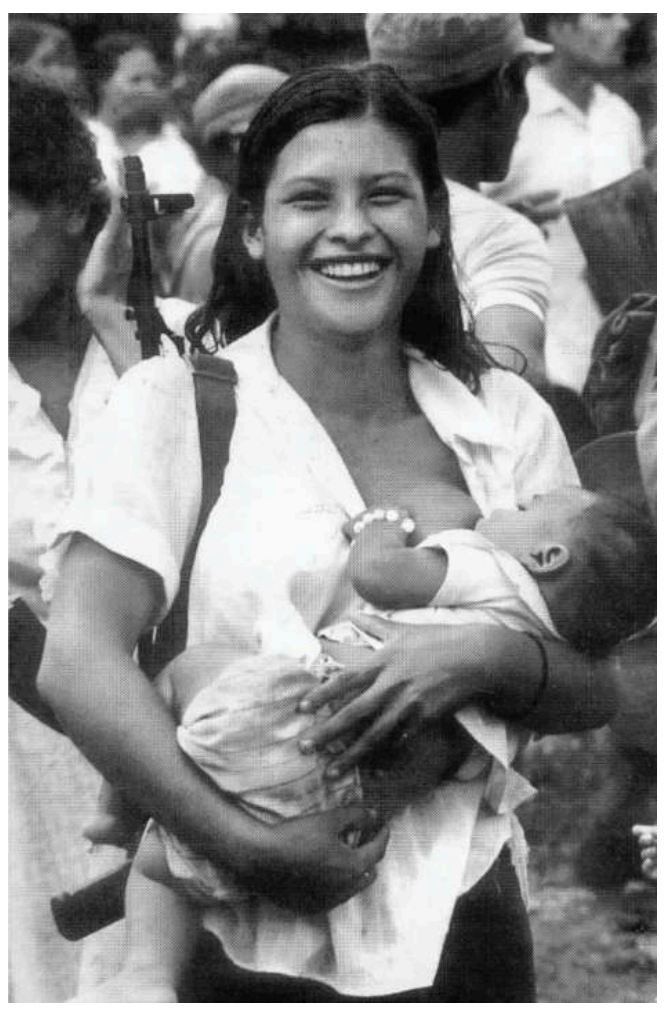

Both of these photographs became iconic representations of armed struggle and what it meant for its protagonists. Guevara's photograph, Guerrillero Heroico, was taken by 
Alberto Korda in 1960 at the funeral of the victims who died on board a French freighter in Havana while unloading munitions. This photograph is known worldwide and construed as the image of the quintessential revolutionary, being often used by the Cuban leadership as a metonymic for the revolution. Guevara is frequently referenced in Central American testimonies as the model "new man" and this image, as the most iconic one of Guevara and the most widely used by the Cuban leadership, can be interpreted as a depiction of the quintessential "new man." Moreover, the use of this photograph as representative of the Cuban revolution (Cambre 2012: 72) seems to suggest that Guevara embodies what are perceived to be the core revolutionary values. The second photograph is not nearly as widely known, but it was very popular during the Sandinista revolutionary decade, not only nationally but also in the international scene. This 1982 photograph was taken by Orlando Valenzuela and came to represent women's involvement in the revolutionary struggle. AMNLAE's use of it in the murals it commissioned contributed to the iconization of this image of female militancy in a way that merged revolutionary goals and women's fight for equal rights.

Women's struggle throughout the Sandinista revolutionary decade and in the postrevolutionary Cuban state would continue to be conflated with the revolution's attempt to stay in power. In Nicaragua, the phrase "no revolution without emancipation, no emancipation without revolution" was widely used in order to present revolutionary and feminine aims as inextricably intertwined (Molyneux 1985). A socialist revolution was seen as necessary for women's attainment of equal rights. Similarly, in Cuba, participation in the revolution was equated with fighting for women's rights, as suggested by the official emblem of the FMC, adopted since its foundation, namely a woman holding a baby to her breast and a rifle slung over her shoulder (Bayard de Volo 2012, Moya Fábregas 2010). Moreover, the images of female militancy and the massive incorporation of women into the workforce were instrumental for the consolidation of the revolution and Castro's patriarchal power.

In her analysis of Cuban women's political participation, Stoner suggests that the appropriation of female militancy is used as a means to authorize "patriarchal systems and construct social order," simultaneously linking "female soldiering with concepts of martyrdom, national suicide, honor, and militant faithfulness to male family members, national leaders, and the state" (2003: 73). Female martyrdom and heroism in militaristic narratives are used to intensify feelings of nationalism that render the individual expendable, thus being central to post-revolutionary state-building and the creation of feelings of devotion for a national identity centered on the idea of independence and egalitarianism achieved through revolution. While the iconic image of female militancy was important for the legitimation of the revolutionary process, it also evinces the revolution's patriarchal biases.

In the new society, women were the ones to be in charge of teaching and passing on revolutionary values from one generation to the next. Childrearing was thus presented as a gendered task, so that, as Moya Fábregas affirms, "[p]atriotism and motherhood became intertwined as the main function of Cuban women" (2010: 72). Bearing children for the revolution was interpreted as the main act of female patriotism by both the Cuban and Nicaraguan leaderships, and this interpretation was validated by AMNLAE's and the FMC's iconization of the militant mother as representative of revolutionary womanhood. In the iconic Miliciana de Waswalito, the guerrillera does not stand alone, but her identity as a female combatant is evinced by the infant she holds to her chest 
and the rifle strapped to her arm. It is her rifle that connects her to the armed struggle, but, more than carrying and using a firearm in the battlefield, it is her ability to nurse a child that makes her a vital part of the revolution. It is the childbearing capabilities of the guerrillera that legitimize her presence in the battlefield since she is fighting for the children she is meant to raise (Molyneux 1985: 228-29). The guerrillera's main aim is to defend the country, and thus the home, and to create a better society for the sake of the children of the revolution, who will also defend the revolution in their turn. Her carrying a firearm seems to be an extension of her caring duties as mother and thus, the presence of the child validates the guerrillera's participation in armed struggle.

The fact that the Federación de Mujeres Cubanas (FMC) adopted an image similar to that of the 1982 Miliciana de Waswalito from 1961 to 2007 as its official emblem seems to suggest that motherhood and childrearing became inextricably attached to the guerrillera's identity. Women appear to fight not for the abstract concept of a nation or independence, but for the future of their children in a better society. The iconic "new man," on the other hand, as represented by the famous Korda photograph, does not need a weapon or a child to validate his status as a revolutionary or suggest the importance of his participation in the armed struggle. As a man, his presence in the battlefield is already legitimate and his ideals suffice as a reason for participation in warfare. The face of Guevara expresses, for revolutionaries, the determination to fight unjust systems and create egalitarian societies. As stated by Cambre in her analysis of the contemporary and historical usage of Korda's photograph, "millions interpellated by the Guerrillero Heroico around the world take up the image as a way of noting the intolerable state of the world, the need to change it, and [...] participate in that change" (Cambre 2012: 83).

Guevara, and his image, became synonymous with the ideals of revolutionary struggle and positive social change. His mere face suffices to "interpellate" people to action and in testimonies of armed struggle, like that of Omar Cabezas, he is taken as the quintessential example of revolutionary manhood:

I get to know about Sandino through el Che; because I realize that in Nicaragua, in order to be like el Che, one has to be Sandinista. (Cabezas 1982: 7)

At midday I had the New Man story stuck in my mind, be like Che, be like Che [...] a man can always give a bit more of himself, only when a man faints or dies can he no longer do so, but as long as he is conscious and standing firm, a man can always give more. (Ibid.: 51) ${ }^{18}$

Even though Sandino was the national hero after whom the leading resistance movement in Nicaragua named their party, it was the mythical reputation and image of Guevara that inspired the young Cabezas and perhaps most of the young revolutionaries who were historically closer to Guevara than to Sandino. According to Cabezas and Guevara, the "new man" is born in the mountains through the overcoming of arduous tasks and selfless sacrifice for the sake of his country, his countrymen, justice and independence.

On the other hand, AMNLAE's and the FMC's representations suggest that the "new woman" is the one who fights to give birth to the new men and women that will continue to defend the revolution. The "new man" produces the conditions in which the "new woman" will reproduce. Thus, the task of the "new man" is the production of the new dominant ideology, while that of the "new woman" is to ensure its reproduction. In short, motherhood and its concomitant household tasks seem to be naturalized as the highest of women's aspirations in the revolutionary society and 
women's most important contribution to the revolution. Furthermore, the political actions taken towards women's liberation in Nicaragua, in spite of the considerable progress made in legislation in 1987, were limited by the prevailing masculinist ideology within revolutionary, seemingly progressive, discourse. The language and representations of revolutionary struggle outlined the social spaces assigned for each gender and these ideological determinations were reflected in the legislative realm through omissions or exclusions in legal reform.

\section{Private Politics and the Public Sphere: Policing Gender through Legislation in Sandinista Nicaragua}

In spite of the Catholic Church's strong influence on the Sandinista revolutionary process, the Sandinista regime also instituted progressive sexual policies. These, however, did not extend to women's reproductive rights or the acknowledgement of alternative family configurations. In the first years after Somoza's overthrow, several legal reforms were pushed by feminist organizations formed during the revolutionary process. One of the first actions of the Sandinista government was to pass, on July 20th, 1979, the Law of the Means of Communication, which prohibited the use of women as sex objects. This law was a response to "one of the most strongly felt demands of women from the time of the AMPRONAC [the Asociación de Mujeres Ante la Problemática Nacional ${ }^{19}$ ]" (p. 126; Junta de Gobierno, 1984, as cited by Kampwirth 1998: 54). This represented a triumph for women in the public sphere and also enhanced the moral character of the revolutionary project without posing a threat to revolutionary masculinity. Indeed, on the same day, other laws were decreed that showcased the feminine influence on, and the prevailing Christian moral character of, Sandinista legislation. One of these laws established penalties to "suppress pimping and prostitution" (Junta de Gobierno, 1984, p.22, Ibid.) and was complemented by a voluntary rehabilitation and employment program for prostitutes. The FSLN's gender policies were thus fashioned to rectify Somoza's legacy of sexual corruption (González 2001: 67). For, the revolutionary "new men" would not "engage in the sexual degradation of women, a characteristic of Somocista masculinity” (González 2001: 47).

These actions by the FSLN government demonstrate that Sandinista ideology, women's interests, and catholic discourse were not always mutually exclusive. Women's liberation was not necessarily perceived as antithetical to revolutionary ideology and subjectivity. In fact, proponents of liberation theology and the FSLN supported women's liberation efforts, when these coincided with Christian social reformation. This support encouraged homosexuals to expect a similar treatment in the legal sphere. However, there were clear boundaries, largely demarcated by patriarchal, Catholic discourse, to what women and sexual minorities could achieve in the legal sphere. As stated by Howe in her analysis of Sandinista gay and lesbian political engagement, "while the FSLN was very 'out of the closet' about the need to address women's rights, the same sentiment was not applied to gay and lesbian rights" (Howe 1999: 17). Indeed, a great part of the efforts to rehabilitate the moral character of society were directed at restoring public sexual order to the nation by not only reeducating prostitutes but also closing gay bars (Kampwirth and McGee 2015: 64).

The fact that prostitution and gay bars were both perceived as threats to the new revolutionary state, showcases the state's tendency to arrogate itself the right to 
regulate gender dynamics through the suppression of "deviant" public gender performances. Both prostitution and the behavior of homosexuals at nightclubs and bars were perceived as detrimental to the nation's moral character, perhaps because both of these "scandalous" sexual behaviors were displayed in public spaces, which belong to the state and are hence regulated by dominant politico-ideological interests. Indeed, before the overthrow of Somoza, the Sandinista guerrilla would accept gay and lesbian compañeros as long as their behavior was not disruptive to other members-that is, so long as the dominant revolutionary gender discourse was not threatened. ${ }^{20}$ This apparent acceptance, however, quickly turned to hostility with the Sandinista state's institutionalization of revolutionary ideology and establishment of a new hegemonic discourse in which there was no space for non-standard sexual behavior. Indeed, once revolutionary masculinity gained hegemony, there was a need to clearly define its limits and its "others" so that its power could be exercised.

In 1985, gay and lesbian Sandinistas, an estimated of 50 to 100 people, started to organize their own gay-lesbian pride political group called Grupo Inicio. However, this movement was very quickly disbanded by the government and "its leaders briefly jailed, intimidated, sometimes stripped of their party membership and jobs" (Ibid.). Moreover, one of the apprehended members was warned by a prison guard that gays "did not have an identity or social space within the revolutionary process because the new man was neither a faggot nor a fag fucker [...], because of that it was easy to confuse [them] with the enemy" (El País, 1992: 8, as cited by Kampwirth 2014: 322). This comment reflects the revolutionaries' need to police private choice when it interferes with the public performance of the masculine, heterosexual "new man". Indeed, "the traditional opposition between the public and the private conceals the extent to which the public is present in the private, and in the very notion of privacy" (Bourdieu 1996: 26). Thus, the state constantly shapes privacy by constantly defining and redefining the limits of the public sphere.

31 Some of the reforms related to gender power dynamics in the public sphere proposed by AMNLAE in the drafting of the 1987 Constitution were not included in the final version. Among the unmet requests was the criminalization of sexual harassment in the workplace (Kampwirth 1998). The failure to criminalize sexual harassment in the workplace, despite the need to reform the moral character of the nation, evidences the patriarchal logic prevalent in the law-making process. Women being harassed in the workplace (a space construed as male-dominated and masculine) was not perceived as antithetical to the revolutionary ethos, whereas public homosexual behavior was offensive to the state. The harassment of women in the workplace does not disrupt, but perpetuate, traditional gender dynamics that protect male privilege. Thus, public spaces, as the sites upon which masculinity is contested, were clearly claimed by the state in their revolutionary, moral reformation project.

Moreover, spaces at the intersection of the public and private spheres (e.g. the family) were also directly impacted by the need to regulate public performances of gender. As stated by Althusser, "an ideology always exists in an apparatus and in the practice or practices of that apparatus. This existence is material" ([1995] 2004: 695). It is thus by means of systematic performance in different ideological apparatuses (e.g. churches, schools, family) that belief systems acquire a material existence that shapes and restricts individuals' identities. Adherence to revolutionary ideology then, had to translate into public and private actions that reiterated the revolutionary belief 
system; and this reiteration was made compulsory for individuals through the Legal Ideological State Apparatus (ISA, Althusser 1970).

In terms of revolutionary gender ideology, family legislation was important because the laws that determine family dynamics and what constitutes a family are expressions of the prevalent ideological discourses and perceptions regarding "how men, women, and children should behave" (Kampwirth 1998: 53). It is through the Legal ISA that "society regulates issues of sexuality when they spill out of the confines of the family, as they inevitably do" (Ibid.). Indeed, in revolutionary Nicaragua there was a clear preoccupation with the choices of private individuals regarding sexuality only insofar as their behavior might disrupt heteronormative perceptions of gender roles and sexuality. This preoccupation led to the hindering of progress in certain aspects of family legislation reform.

In 1980 there was an amendment to the Adoption law, proposed to the Council State by AMNLAE, which allowed single citizens to adopt regardless of their gender (Kampwirth 1998: 54). Additionally, the "Somoza-era concept of 'patria-potestad' or absolute paternal power" was abolished and replaced by shared custody (55). Following this, the very controversial Nurturing law, proposed in 1982, required that all household members be equally responsible for domestic tasks and childcare. This law was diametrically opposed to prevalent hierarchical family dynamics in which the private sphere (the household) and all the tasks pertaining to it were gendered feminine and thus feminizing. This law was therefore never ratified. Indeed, men and women being held equally responsible for carrying out domestic tasks was construed as emasculating or as undermining masculine revolutionary subjectivity in the context of Sandinista Nicaragua. Interestingly, a similar law in the 1975 Cuban family code was passed and met with the same reservation and no mechanisms were established to promote adherence.

In 1987, AMNLAE successfully presented a proposal to reform the family code to expand the definition of family, abolish the category of "illegitimacy" and demand equal responsibility of men and women in childcare, among other progressive legislation. Notwithstanding the achievements reflected in the 1987 Constitution, some argue that the broadened definition of family does not admit the possibility of homosexual couples. ${ }^{21}$ Article 72 of the Constitution uses language that "makes clear that the state does not protect marriages or de facto unions between homosexuals" (Barton, 1988, p. 60 as cited by Kampwirth 1998). This can be interpreted as springing from reluctance to disrupt traditional notions of gender and a necessity to endorse heterosexist family dynamics. Admitting that a family might be constituted by homosexual individuals would have posed a threat to traditional conceptions of gender within the family, which is one of the pillars of nationalist masculinity. The "new man" in Sandinista Nicaragua was understood to be a catholic revolutionary, capable of fulfilling the role of the traditional husband whose main tasks were undertaken outside the household, that is, in the male-dominated public sphere.

Although the 1987 constitution guaranteed many fundamental women's rights and established more egalitarian relations in the household, there were reforms requested by AMNLAE regarding private politics that did not make it into the Constitution, such as women's right to abortion and thus the possibility to have effective agency over their reproductive capabilities. The legislative omissions and exclusions in the 1987 Constitution reflect the revolutionary value system which can be construed as an 
"intriguing mix that comes from blending Sandinismo, [...] Marxism [...], and liberation theology [...] into a single ideology" (Azicri 1989: 29). This blend did not help advance the reproductive rights of women, however. Contraceptive measures, family planning and abortion were vilified by proponents of liberation theology and rejected by the FSLN, both claiming that these represented further U.S. infiltration into the national culture. Prevalent masculinist biases gave way to an anti-imperialist interpretation of feminism. Feminist concerns were then construed as foreign imports, whereas nonthreatening, and thus feminine, political action was openly endorsed. In fact, whatever advances were made towards equality could be undone by the male revolutionary leadership in charge of legislation. Clearly, the possibilities of revolutionary womanhood were greatly defined by what revolutionary masculinity was willing to accede to.

The political participation of women was thus limited by the subject positions that men were willing to occupy or share with women without risking the loss of privilege and thus, marginalization and feminization. In fact, there was a strong tendency for demands that defied party interests and male privilege to be labelled feminist and antirevolutionary. The discourse that constructed Sandinismo and feminism as antagonistic served to both silence and discipline women who attempted "to tackle the double standards, sexual harassment, and homophobia they lived within the party" (Heumann 2014: 302). Feminism within the revolutionary context was thus persistently cast as a disruptive force that would destabilize traditional conceptions of gender and family. Therefore, acceptable feminine political involvement was that which was perceived as innocuous to the new hegemonic masculine/masculinist revolutionary discourse and identity. The place of the "new men" in society would not be redefined by the demands of the "new women."

\section{Conclusions}

In revolutionary Nicaragua, there was a high value placed on work that was undertaken outside the home. Indeed, support for the revolution translated into work undertaken in the public sphere, so that being productive was equated with carrying out activities outside the familial sphere. There was not, therefore, a reevaluation of the gendered character of spaces, but rather a need to have women participate in the traditionally masculine sphere, while they remained the primary responsible for housework and domestic affairs. Moreover, the call for women's massive participation in the public sector was not concomitant with a reevaluation of fatherhood and the role of men in the family, so that while revolutionary law and morality aimed towards freeing the proletariat and campesinos, they neglected to effectively address the subversion of sexist prejudices that shaped family and social relations.

In spite of the initial innovative and subversive character of the Sandinista movement, conservative notions of family and gender, as well as the symbolic power of religion continued to impose themselves through/on state and social actors. Even when laws seem to guarantee equality, the absence of legal mechanisms of repression cannot be equated with the eradication of the ideology that legitimizes the subordination and suppression of the feminine. Althusser warns against expanding the political meaning of repression, since when this happens, there is a tendency for "repression" to simultaneously "stand in for exploitation, ideology and, ultimately, the state as well," 
which is comprised of "both a repressive apparatus and ideological apparatuses that are reduced to the abstract notion of "repression"' ([1995] 2014: 179). Therefore, abolishing repressive mechanisms does not automatically annul the ideology that engendered and legitimated the exercise of these mechanisms in the first place.

Ideology should not be mistaken for the repressive mechanisms that sustain it, for even after repressive mechanisms are taken away by laws that defend women's rights, patriarchal ideology persists in various forms and so does exploitation in the form of unequal pay, unequal participation in household and caring tasks, societal condemnation of women who "neglect" the home and the idealization of motherhood. It was thus not enough to expand the limits of revolutionary femininity: a serious and balanced reevaluation of the social importance of the domestic/private and public spheres was needed in Nicaragua in order to create masculinities that would have allowed for greater equality.

\section{BIBLIOGRAPHY}

Althusser, Louis, [1970] 2004, "Ideology and Ideological State Apparatus," in Literary Theory: An Anthology, ed. J. Rivkin and M. Ryan, Oxford, Blackwell, pp. 693-702.

Althusser, Louis, [1995] 2014, On the Reproduction of Capitalism: Ideology and Ideological State Apparatuses, trans. G.M. Goshgarian, London, Verso.

Andaya, Elise, 2014, Conceiving Cuba: Reproduction, Women, and the State in the Post-Soviet Era, New Brunswick, Rutgers University Press.

Asamblea Nacional, 2014, Ley 870, Código de Familia, Managua, Nicaragua.

Asamblea Nacional del Poder Popular, 1997, Ley 62, Código Penal, Havana, Cuba.

Atkinson, Will, 2013, “A Sketch of 'Family' as a Field: From Realized Category to Space of Struggle," Acta Sociologica, vol. 57, no. 3, pp. 223-35.

Azicri, Max, 1989, “The 1987 Nicaraguan Constitution: An Analytical Commentary," Review of Socialist Law, vol. 15, no. 1, pp. 5-29.

Bayard de Volo, Lorraine, 2012, "A Revolution in the Binary? Gender and the Oxymoron of Revolutionary War in Cuba and Nicaragua," Signs: Journal of Women in Culture and Society, vol. 37, no. 2, pp. 413-39.

Borge, Tomás, Fonseca, Carlos, Ortega, Daniel, Ortega, Humberto, and Wheelock, Jaime, 1982, Sandinistas Speak, ed. Bruce Marcus, New York, Pathfinder Press.

Bourdieu, Pierre, 1996, "On the Family as a Realized Category," Theory, Culture \& Society, vol. 13, no. 3, pp. 19-26.

DOI : $10.1177 / 026327696013003002$

Cabezas, Omar, 1982, La montaña es algo más que una inmensa estepa verde, Managua, Nueva Nicaragua. 
Cambre, Maria-Carolina, 2012, "Stealing or Steeling the Image? The Failed Branding of the Guerrillero Heroico Image of Che Guevara," Imaginations Archives, vol. 3, no. 1, pp. 64-87.

Chase, Michelle, 2015, Revolution within the Revolution: Women and Gender Politics in Cuba, 1952-1962, Chapel Hill, The University of North Carolina Press.

Fonseca Amador, Carlos, 1982, “Ideario Político del General Sandino," Viva Sandino. Managua, Nicaragua, Editorial Nueva Nicaragua.

González, Victoria, 2001, "Somocista Women, Right-Wing Politics, and Feminism in Nicaragua, 1936-1979," Radical Women in Latin America: Left and Right, University Park, Pennsylvania State University Press, pp. 41-78.

Guevara, Ernesto, [1960] 1972, “Guerra de Guerrillas," Escritos y discursos, ed. J. J. Soto Valdespino, vol. 1, La Habana, Editorial de Ciencias Sociales.

Guevara, Ernesto, 1975, Escritos y discursos, ed. J. J. Soto Valdespino, vol. 7, La Habana, Editorial de Ciencias Sociales.

Guevara, Ernesto, [1965] 1977, "Socialismo y el Hombre en Cuba," in Escritos y discursos, ed. J. J. Soto Valdespino, vol. 8, La Habana, Editorial de Ciencias Sociales.

Guevara, Ernesto, [1964], "Ernesto ‘Che' Guevara Addressing the General Assembly," United Nations Radio Classics, United Nations, [Online], https://www.unmultimedia.org/classics/asset/ C816/C816/, accessed on 26 November 2019.

Hariman, Robert, and Lucaites, John Louis, 2007, No Caption needed: Iconic Photographs, Public Culture, and Liberal Democracy, Chicago, University of Chicago Press.

Heumann, Silke, 2014, "Gender, Sexuality, and Politics: Rethinking the Relationship Between Feminism and Sandinismo in Nicaragua," Social Politics: International Studies in Gender, State \& Society, vol. 21, no. 2, pp. 290-314.

DOI: $10.1093 / \mathrm{sp} / \mathrm{jxu} 004$

Howe, Alyssa C., 1999, "Nicaraguan Gay and Lesbian Rights and the Sex of Post-Sandinismo," University of New Mexico's Research Paper Series, 33, pp. 1-33.

Kampwirth, Karen, 1998, “Legislating Personal Politics in Sandinista Nicaragua, 1979-1992," Women's Studies International Forum, vol. 21, no. 1, pp. 53-64.

DOI: $10.1016 /$ S0277-5395(97)00083-6

Kampwirth, Karen, 2006, "Resisting the Feminist Threat: Antifeminist Politics in Post-Sandinista Nicaragua," NWSA Journal, vol. 18, no. 2, pp. 73-100.

Kampwirth, Karen, 2013, "Organising the Hombre Nuevo Gay: LGBT Politics and the Second Sandinista Revolution," Bull Lat Am Res, vol. 33, no. 3, pp. 319-33.

DOI: $10.1111 /$ blar.12068

Kampwirth, Karen and McGee, Marcus J., 2015, "The Co-Optation Of LGBT Movements In Mexico And Nicaragua: Modernizing Clientelism?," Latin American Politics and Society, vol. 57, no. 4, pp. 51-73.

DOI: $10.1111 / \mathrm{j} .1548-2456.2015 .00290 . \mathrm{x}$

Korda, Alberto, 1960, Guerrillero Heroico, [Online], https://en.wikipedia.org/wiki/ Guerrillero_Heroico, accessed on 26 November 2019.

Kunzle, David, 1995, The Murals of Revolutionary Nicaragua, 1979-1992, Berkeley, CA, University of California Press. 
Lancaster, Roger N., 1994, Life is Hard: Machismo, Danger, and the Intimacy of Power in Nicaragua, Berkeley, University of California Press.

Larson, Jeff A., and Lizardo, Omar, 2007, "Generations, Identities, and the Collective Memory of Che Guevara 1," Sociological Forum, vol. 22. no. 4, [Online], DOI: 10.1111/j.1573-7861.2007.00045.X, accessed on 26 November 2019.

Luciak, Ilja A., 2001, After the Revolution: Gender and Democracy in El Salvador, Nicaragua, and Guatemala, Baltimore, Johns Hopkins University Press.

Lumsden, Ian, 1996, Machos, Maricones, And Gays: Cuba and Homosexuality. Philadelphia, PA, Temple University Press.

Molyneux, Maxine, 2001, "State, Gender and Institutional Change: The Federación de Mujeres Cubanas," in Women's Movements in International Perspective, Palgrave Macmillan UK, pp. 76-98. DOI: $10.1057 / 9780230286382 \_5$

Molyneux, Maxine, 1998, “Analysing Women's Movements," Development and Change, vol. 29, no. 2, pp. 219-45.

DOI: https://doi.org/10.1111/1467-7660.00077

Montoya, Rosario, 2003, "House, Street, Collective: Revolutionary Geographies and Gender Transformation in Nicaragua, 1979-99," Latin American Research Review, vol. 38, no. 2, pp. 61-93, [Online], https://www.jstor.org/stable/1555420, accessed on 26 November 2019.

Mooney, Jadwiga Pieper, 2009, The Politics of Motherhood: Maternity and Women's Rights in TwentiethCentury Chile, Pennsylvania, University of Pittsburgh Press.

Moya Fábregas, Johanna I., 2010, “The Cuban Woman's Revolutionary Experience: Patriarchal Culture and the State's Gender Ideology, 1950-1976," Journal of women's history, vol. 22, no. 1, pp. 61-84.

DOI: 10.1353/jowh.0.0134

Plaza Azuaje, Penélope, 2010, "Madre armada y niño. Representación de la Mujer Nueva en los murales de la Revolución Sandinista en Nicaragua," Apuntes. Revista de estudios sobre patrimonio cultural, vol. 23, no. 1, [Online], https://revistas.javeriana.edu.co/index.php/revApuntesArq/ article/view/8915, accessed on 26 November 2019.

Randall, Margaret, 2009, To Change the World: My Years in Cuba, New Brunswick, N.J., Rutgers University Press.

Rodríguez, Ileana, 1996, Women, Guerrillas, and Love, Minneapolis, University of Minnesota Press.

Saldaña-Portillo, María Josefina, 2003, The Revolutionary Imagination in the Americas and the Age of Development, Durham, Duke University Press.

Stoner, K. Lynn, 2003, “Militant Heroines and the Consecration of the Patriarchal State: The Glorification of Loyalty, Combat, and National Suicide in the Making of Cuban National Identity," Cuban Studies, vol. 34, no. 1, pp. 71-96.

DOI: $10.1353 /$ cub.2004.0028

Valenzuela, Orlando, 1984, Miliciana de Waswalito, Reproduced with author's permission, [Online], https://nicaraguainternacionalista2016.wordpress.com/2016/03/27/la-miliciana-de-waswalitoel-destino-mundial-de-una-fotografia/, accessed on 26 November 2019. 


\section{NOTES}

1. Translation from The Che Reader (Ocean Press, 2005). Available on Marxist Internet Archive: https://www.marxists.org/archive/guevara/1965/03/man-socialism.htm. "Los dirigentes de la Revolución tienen hijos que en sus primeros balbuceos, no aprenden a nombrar al padre, mujeres que deben ser parte del sacrificio general de su vida para llevar la Revolución a su destino; el marco de los amigos responde estrictamente al marco de los compañeros de Revolución. No hay vida fuera de ella" (Guevara [1965] 1977: 270). We translate all quotations from Spanish.

2. Examples of this can be found across Latin America (e.g. Madres de la Plaza de Mayo in Argentina, Centros de Madres in Chile, see The Politics of Motherhood by Mooney 2009). See also Michelle Chase (2015).

3. Reflective of the tendency to feminize inaction or non-adherence to revolutionary ideology is Guevara's intervention in December 11th, 1964 at a UN General Assembly: https://www.unmultimedia.org/classics/asset/C816/C816/.

4. This work won the Casa de las Américas award in the category of testimonio and was translated as Fire from the Mountain by Kathleen Weaver in 1986.

5. This was a military Sandinista operation for the kidnapping of Somocista functionaries in order to ask for the release of high-ranking Sandinista officers, the opportunity to broadcast their political message in national means of communication and get ransom money destined for the Sandinista cause.

6. Translation from The Che Reader, Ocean Press, 2005. Available on Marxist Internet Archive: https://www.marxists.org/archive/guevara/1965/03/man-socialism.htm. "Llegó la etapa de la lucha guerrillera. Esta se desarrolló en dos ambientes distintos: el pueblo, masa todavía dormida a quien había que movilizar y su vanguardia, la guerrilla, motor impulsor de la movilización, generador de conciencia revolucionaria y de entusiasmo combativo. Fue esta vanguardia el agente catalizador, el que creó las condiciones subjetivas necesarias para la victoria. [...] Fue la primera época heroica, en la cual se disputaban por lograr un cargo de mayor responsabilidad, de mayor peligro, sin otra satisfacción que el cumplimiento del deber. [...] En la actitud de nuestros combatientes se vislumbra al hombre del futuro." (Guevara [1965] 1977: 254)

7. It must be noted that Tomás Borge is infamous for suspected corruption both during the first Sandinista government and his subsequent political positions. See Margaret Randall (2009). Therefore, it is unclear to what extent the revolutionary leadership actually attempted to temper abuses, especially in light of La Piñata of 1990.

8. According to Kampwirth, "both feminist activists and their opponents credit-or blame-the mobilization of women in the guerrilla struggle and the revolution for the emergence of feminism" (1998: 76).

9. See Rodríguez (1996: 19-20).

10. Castro famously claimed that women's political participation in the revolutionary process constituted "a revolution within the revolution." See Chase (2015).

11. The vast majority of the murals from the Sandinista period were destroyed during the 1990s by orders of Arnoldo Alemán, elected mayor of Managua, in an attempt to erase all traces of the recent Sandinista past. Pictures of these murals can still be found in Kunzle's The Murals of Revolutionary Nicaragua (1995). 
12. Own translation. "[E]n esta época [la mujer] puede desempeñar sus tareas habituales de la paz y es muy grato para el soldado [...] el poder contar con una comida sazonada [...] [L]a mujer presta un papel importante como enfermera, incluso médico, con ternura infinitamente superior a la del rudo compañero de armas [...] En todos los otros órdenes de la organización civil, la mujer presta su concurso y puede reemplazar perfectamente al hombre y lo debe hacer hasta en el caso de que falten brazos para portar armas, aunque esto es un accidente rarísimo en la vida guerrillera."

13. See Guevara's 1963 speech to the general assembly of workers at the Textilería Ariguanabo in Escritos y Discursos, Volume 7 (1975: 39-54).

14. See Chase (2015), Andaya (2014), Molyneux (1998).

15. Own translation. "La revolución aparece como una cualidad exclusivamente masculina, y [...] la imagen de la mujer combatiente es relegada a un rol secundario. [...] [Los murales] son abrumadoramente optimistas, llenos de promesas de una mejor vida, [...] un mundo de juegos con niños que corren libremente bajo la mirada de madres felices."

16. As Luciak states, "[i]t was not until 1994 that women were elected to the FSLN's National Directorate," which held all the decision-making power during the revolutionary decade (2001: 171).

17. See Larson and Lizardo (2007). For a detailed analysis on the iconization of images, their influence in the creation of collective memory and their cultural and sociopolitical significance, see Chap. 2 in Hariman and Lucaites (2007).

18. "Yo conozco y llego a Sandino através del Che, porque me doy cuenta que en Nicaragua para ser como el Che hay que ser sandinista" (Cabezas 1982: 7); "Ya mediodía yo llevaba en la mente la película del hombre nuevo, ser como el Che, ser como el Che [...] el hombre siempre puede dar un poco más, sólo cuando el hombre se desmaya o se muere, pero mientras esté consciente todavía y está de pie y no se cae, el hombre siempre puede dar más" (Ibid.: 51).

19. Sandinista-affiliated women's association, operative from 1977-1979, in which year it turned into AMNLAE.

20. See Kampwirth and McGee (2015: 51-73), and Kampwirth, (2013: 319-33).

21. Some others like Roger Lancaster (1992) have suggested that the language of the family code was rather ambiguous and could be broadly interpreted to include homosexual couples. Tellingly, the definition of family was recently changed under the new Sandinista government to specifically exclude homosexual couples. According to article 7 of the family code: "A family is constituted by a group of people [...] united by marriage or a civil stable union between a man and a woman, and those bound by kinship" (Ley 870: Código de Familia, Asamblea Nacional, 2014: 35). 


\section{ABSTRACTS}

This paper explores how public and private performances of gender were impacted by Sandinista revolutionary ideology and discourse in 1980s Nicaragua. In order to pinpoint the problematic aspects of Sandinista discourse, this analysis breaks down key political texts and images that shaped Latin American revolutionary discourse, as well as texts that were used or popularized by the Sandinista revolutionary leadership in relation to men's and women's role within the revolutionary process. The logic that permeates the analysed material evinced a clear masculinist, heterosexist bias that had an impact on political decision-making regarding women's rights. In the institutionalization of revolutionary ideology and its translation to legislative reforms, there were clear boundaries to what the revolutionary male leadership would accede to in terms of women's reproductive rights, women's role in the public sphere and men's role in the domestic sphere. This analysis concludes that Sandinista revolutionary discourse and policies rather than subvert, reiterated pre-revolutionary gender roles and expectations, in spite of the Sandinista revolutionary movement's professed goal of achieving gender equality.

Cet article explore l'impact de l'idéologie et du discours révolutionnaires sandinistes des années 1980 au Nicaragua sur les performances publiques et privées en matière de genre. Afin d'identifier les aspects problématiques de l'idéologie et du discours sandinistes, cette analyse décompose les principaux textes et images politiques qui ont façonné le discours révolutionnaire latino-américain, ainsi que les textes utilisés ou popularisés par la direction révolutionnaire sandiniste en relation avec le rôle des hommes et des femmes dans le processus révolutionnaire. La logique qui imprègne le matériel analysé révèle un parti pris clairement masculiniste et hétérosexiste qui a eu un impact sur la prise de décision politique concernant les droits des femmes. Dans l'institutionnalisation de l'idéologie révolutionnaire et sa traduction en réformes législatives, il y avait des limites claires concernant ce que la direction sandiniste était prête à accorder en termes de droits reproductifs des femmes, et concernant le rôle des femmes dans la sphère publique et celui des hommes dans la sphère domestique. Cette analyse conclut que le discours et les politiques révolutionnaires sandinistes, plutôt que de les remettre en question, ont réitéré les rôles de genre traditionnels, en dépit de l'objectif déclaré du mouvement d'atteindre l'égalité des sexes.

\section{INDEX}

Mots-clés: masculinité, féminité, discours révolutionnaire, performance, idéologie, Homme Nouveau, féminisation, identité hégémonique, Nicaragua

Keywords: masculinity, femininity, revolutionary discourse, performance, ideology, New Man, feminization, hegemonic identity, Nicaragua

\section{AUTHOR}

\section{VIRIA DELGADILLO}

Duisburg-Essen Universität 